\begin{tabular}{|c|c|c|}
\hline & Int.J.Curr.Microbiol.App.Sci (2021) 10(08): 500-509 & \\
\hline & $\begin{array}{l}\text { International Journal of Current Microbiology and Applied Sciences } \\
\text { ISSN: 2319-7706 Volume } 10 \text { Number } 08 \text { (2021) } \\
\text { Journal homepage: http://www.ijcmas.com }\end{array}$ & $\$ 198$ \\
\hline $\begin{array}{l}\text { EXCELLENT } \\
\text { PUBLISHERS }\end{array}$ & & wwwidijmascom \\
\hline
\end{tabular}

Original Research Article

https://doi.org/10.20546/ijcmas.2021.1008.060

\title{
Temperature Accelerates Photoperiod Mediated Testicular Maturity in Clarias magur (Hamilton, 1822)
}

\author{
Srijit Chakravarty ${ }^{1}$, N. K. Chadha ${ }^{1}$, B. K. Mahapatra ${ }^{2}$, \\ Paramita Bannerjee Sawant ${ }^{1}$ and Subrata Dasgupta ${ }^{2} *$ \\ ${ }^{1}$ Department of Aquaculture, ICAR-Central Institute of Fisheries Education, \\ Versova, Mumbai - 400061, India \\ ${ }^{2}$ ICAR-Central Institute of Fisheries Education Kolkata Centre, Kolkata - 700091, India \\ *Corresponding author
}

Keywords

Clarias magur,

Male maturity,

Photoperiod,

Above ambient

Temperature,

Histology

Article Info

Accepted:

20 July 2021

Available Online:

10 August 2021
In teleost fishes exhibiting circadian rhythm in their breeding behavior, the major determinants controlling the annual reproductive cycle are the Photoperiod and temperature. Manipulation of these two parameters can cause significant changes in the gonadal maturity of the air breathing as well as non-air breathing fishes and is widely documented. In this study, male Clarias magur individuals $(n=150)$ were subjected to different combinations of photoperiod, ambient and above ambient temperature to see their effect on the gonadal maturity status of the fishes in early recrudescent phase (February- March). Combination of long photoperiod (14L: $10 \mathrm{D})$ and above ambient temperature $\left(28^{\circ} \mathrm{C}\right)$ has a profound effect on the gonadal maturity of the male Clarias magur which is exhibited by significant changes in GSI, SVSI and gonadal histology. This study shows it is possible to get mature male Clarias magur individuals in as early as in the month of April or May, using a very very simple farmer friendly setup, to start the breeding cycle before the monsoon arrives.

\section{Introduction}

FAO has defined Aquaculture as the farming of aquatic organisms including fish, mollusc, crustaceans and aquatic plants. Farming implies some sort of intervention in the rearing process to enhance production, such as regular stocking, feeding, protection from predators, etc (FAO, 1988). This control is usually practiced to attain better gain in terms of economic yield from the produce to justify the input cost incurred in implementing the control. Nowadays, controlled reproduction and year-round availability of quality seed is a 
challenge for the fish farmers for the expansion of their farming activities (Bisht $e t$ al., 2013).

Photoperiod or the availability of light remains an effective "noise free" environmental factor controlling the sexual maturation in fishes and is well documented in numerous studies and reviews (Bromage, 2001; Al Khamees, 2009). It is a well-accepted fact that photoperiod manipulation can alter the sexual maturity in many air breathing (Sundarraj et al., 1970; Garg and Sundarraj, 1985; Garg and Jain, 1985; Garg, 1987; Senthilkumaran and Joy., 1995; Gupta et al., 2002; Singh et al., 2017; Chaube et al., 2020) as well as non-air breathing fishes (Bhattacharya et al., 2003; Maitra et al., 2005, 2006, 2007; Sarkar et al., 2010). This technology involves simulating the ideal conditions for gonadal maturity as experienced in wild by putting a controlled (duration) artificial light source and near the fish holding unit to either delay or expedite the maturity of the fishes. It was reported that though photoperiod is effective for illiciting steroidogenesis as well as gametogenesis in the pre-spawning phases, this technique is not effective in spawning phases and thus can only be used for helping the fishes attain sexual maturity under captivity (Maitra et al., 2006).

Clarias magur is an indigenous crepuscular nocturnal catfish native to India and Bangladesh and has been accredited a status of Endangered by IUCN vide reference number 123251 (Srivastava and Chowdhury, 2010; IUCN, 2020). The reproductive cycle of the catfish is divided into seven phases, i.e. midquiescence (January), late-quiescence (February), early recrude scence (March), mid-recrudescence (April), laterecrudescence (May-June), spawning (July) and latespawning phase (August) (Priyadarshini and Lal, 2018). Hatchery production of seed of this catfish is still limited to the monsoon months (July-August) and thus year round seed availability is a challenge to all fish farmers. Furthermore, the problem of nonsynchronous maturity of the male and female brooders kept in captivity is experienced for these fishes. Photo thermal manipulation has been validated as a standardized and patented technology in Indian Major Carps to get the year round production of seeds (Sarkar et al., 2010). The hatchery technology of Clarias magur involves the sacrifice of the male brooders to yield sperm suspension and the spontaneous release of milt under captivity has not been achieved on a mass scale yet. Based on the above observations, this study was designed to investigate the effect of temperature coupled with long photoperiod on the specific sex (male) of Clarias magur.

\section{Materials and Methods}

\section{Experimental design}

The experiment was conducted at the wet lab facility of the ICAR-Central Institute of Fisheries Education, Kolkata Centre (N 22 ${ }^{\circ}$ $\left.34.228763^{\prime} \mathrm{E} 88^{\circ} 25.677498^{\prime}\right)$, under controlled conditions for 60 days (Feb 2019-March 2019). Adult Male Clarias magur $(\mathrm{n}=150$; Avg. Length $27.8 \pm 1.005 \mathrm{~cm}$. Avg. length $102.8 \pm 3.93 \mathrm{~g}$ ) were procured from a local fish farm and kept in FRP tanks in Chlorine free ground water(6'x 2.5', Volume=2000 L) with 6 " soil bed for acclimatization for 15 days. During this period, and for the entire study period, the fishes were fed with good quality pelleted feed $(\mathrm{CP}=32 \%$ ABIS pelleted feed $)$ and the water quality parameters were maintained within normal limits by siphoning $30 \%$ of the water every alternate day.

After acclimatization, the fishes were randomly segregated in 2treatment groups viz., treatment 1 (Long Photoperiod 1,14L: $10 \mathrm{D}$ with above ambient temperature, $28{ }^{\circ} \mathrm{C}$ ), treatment 2 (Long Photoperiod 2,16 L: 8D; 
with above ambient temperature, $28^{\circ} \mathrm{C}$ ) and Three control groups; $\mathrm{C}_{0}$ (ambient photoperiod i.e., 11L: 13D and temperature, $\left.21 \pm 1.5^{\circ} \mathrm{C}\right), \mathrm{C}_{1}(14 \mathrm{~L}: 10 \mathrm{D}$ Photoperiod; ambient temperature, $\left.21 \pm 1.5^{\circ} \mathrm{C}\right)$ and $\mathrm{C}_{2}(16 \mathrm{~L}$ : 8D Photoperiod; ambient temperature, $21 \pm$ $1.5^{\circ} \mathrm{C}$ ) following completely randomized design (CRD) in triplicate.

The tanks used for the treatment as well as control (except $\mathrm{C}_{0}$ ) were covered with blacktarpaulin cover to prevent the entry of external light. 2 LED bulbs (5W, Phillips, India) were used for each tank and the photoperiod was controlled using a programmable electronic timer (Blackt Electrotech, India). The temperature of the treatment tanks ( $\mathrm{T} 1$ and $\mathrm{T} 2$ respectively) were maintained within $28{ }^{0} \mathrm{C}$ using two thermostats in each tank (RS 1000, RS Electricals, China). The fishes were sampled monthly for the advancement of maturity and other growth and reproductive parameters (GSI, SVSI). Water quality parameters were sampled every week during the entire study period. The Experimental Design is elucidated in Fig 1 for easy reference.

\section{Reproductive parameters}

\section{Gonadosomatic index}

The Gonadosomatic index (GSI) was calculated by using the following formula:

GSI $=($ weight of gonads/ total body weight $) \times$ 100

\section{Seminal Vesicle somatic index (SVSI)}

The Seminal Vesicle somatic index (SVSI) was calculated as per Chowdhury and Joy (2001):

SVSI $=$ (weight of Seminal vesicles $/$ total body weight) $\times 100$

\section{Water quality parameters}

Dissolved oxygen, $\mathrm{pH}$, Alkalinity, Hardness and Ammonia were measured following the standard guidelines (APHA, 1995).

\section{Histopathology of testis and relative abundance of testicular cell types}

The animals were anaesthetized with clove oil $(50 \mu 1 / 1)$ until they remained motionless. The testes of fish taken from different treatments were dissected out and were fixed in neutral buffer formalin for 24 hours following which they were stored in $70 \%$ ethanol until analysis.

After fixation, the tissues were dehydrated in ascending grades of ethanol, cleaned in xylene and embedded in paraffin wax $\left(58-60^{\circ} \mathrm{C}\right)$.

Section of $4-5 \mu \mathrm{m}$ thickness were cut using a rotary microtome (Leica RM2235, Germany) and stretched on albumenized slide. The slides were fixed at $60^{\circ} \mathrm{C}$ overnight. The next morning, sections were deparaffinised in three changes of xylene (Merck, Germany) and dehydrated in descending grades of alcohol to distilled water. The slides were stained in Haematoxylin (Merck, Germany) for $20 \mathrm{~min}$, differentiated in $1 \%$ of alcohol and blued in Schott's tap water. After washing, sections were stained with eosin (working) for $10 \mathrm{~min}$ (Merck, Germany). Dehydrated and cleaned sections were then mounted in DPX (Merck, Germany) and observed under microscope (DM4000M. Leica, Germany) to record gonadal changes through microphotography. Cells in different stages of spermatogenesis (spermatogonia, spermatocytes, spermatids/ spermatozoa), were counted from twenty different fields in various regions of testis. The percentage of three different stages was then calculated for each field against the total number of cells present in that field; the mean of twenty fields was calculated for each category as per Swapna et al., (2006). 


\section{Statistical analysis}

The data were subjected to one-way analysis of variance (ANOVA) test followed by Duncans Multiple Range Test (DMRT) after Arcsine transformation for GSI and SVSI results. The statistical package used is SPSS 26.0 computer program (SPSS Inc., Chicago, IL). The value $\mathrm{P}<0.05$ was considered statistically significant. All values were expressed as the means \pm standard error of the mean.

\section{Results and Discussion}

\section{Water quality parameters}

Water quality parameters of the tanks showed that Dissolved Oxygen and Ammonia contents of the tanks were $4.0-8.5 \mathrm{mg} / \mathrm{L}$ and $0.01-0.05$ $\mathrm{mg} / \mathrm{L}$ respectively, while temperature was in the range of $26-28.0{ }^{\circ} \mathrm{C}$ and $\mathrm{pH}$ varied between 6.5 and 7.5. The alkalinity of the water varied between $70-120 \mathrm{mg} / \mathrm{L}$ as $\mathrm{CaCO}_{3}$ and Hardness was measured as $110-150 \mathrm{mg} / \mathrm{L}$ as $\mathrm{CaCO}_{3}$. No significant variations were seen between or within the treatments ( $p>0.05)$.

\section{Reproductive parameters}

\section{Gonadosomatic Index (GSI)}

The trends for the gonadosomatic index (GSI; Fig. 2) shows that the GSI for $T_{1}$ (14L: 10D) is significantly higher than all the treatments and controls tested $(\mathrm{F}=5.049 ; \mathrm{P}<0.05)$. The group $\mathrm{T}_{2}$ (16L: $\left.8 \mathrm{D}\right)$ also registered a marginally higher GSI $(0.218 \pm 0.027)$ than respective control $\mathrm{C}_{2}(0.203 \pm 0.025)$ but the difference is insignificant. The GSI in the negative control (No Photoperiod, Ambient Temperature) remained the lowest (0.150.215 ) during the study and the controls with Photoperiod (C1 and $\mathrm{C} 2)$ registered marginally higher GSI during the course of study $(0.204 \pm 0.022$ and $0.203 \pm 0.023)$ respectively. The GSI of treatment group T1 showed a positive trend in increase as the study progressed.

\section{Seminal Vesicle Somatic Index (SVSI)}

Following the trends of GSI, the SVSI also showed variations in the Treatments (Fig. 3) and the T1 registered highest SVSI $(0.0266 \pm$ $0.0014)$ as the study progressed. The Negative control (C0) had the lowest SVSI $(0.019 \pm$ 0.002 ) while the SVSI was marginally higher in the controls with photoperiod (C1: $0.023 \pm$ $0.0015 ; \mathrm{C} 2: 0.0203 \pm 0.0008)$. There was significant difference between the SVSI of T1 and $\mathrm{T} 2(\mathrm{~F}=4.985, \mathrm{P}<0.05)$ after $2^{\text {nd }}$ sampling (40 days of study).

\section{Gonadal histology and Relative abundance of testicular cells}

The histopathology of the testis (Fig 4) shows that the in negative control (C), the spermatogenesis was arrested to the pre recrudescence stage and the lobules of the testis were filled with spermatocytes (SC) waiting to be differentiated (Fig. 4A).

However, in the positive control parallel to Treatment 1 (i.e., C1), there was increase in the number of Secondary Spermatocytes (SSC) and the lobules seem a bit dilated (Fig. 4) in comparison to the negative control. Similar trend was observed in the lobules of the parallel control to treatment 2 (i.e., C2).

There was noted difference in the cell types in the Treatment 1 (Plate 4A) where the lobules can be seen to be full of mature spermatozoa (SZ) and this resembles the testis of the milting male testis of Clarias batrachus which is available in May-June months. 
Fig.1 Experimental design of the study
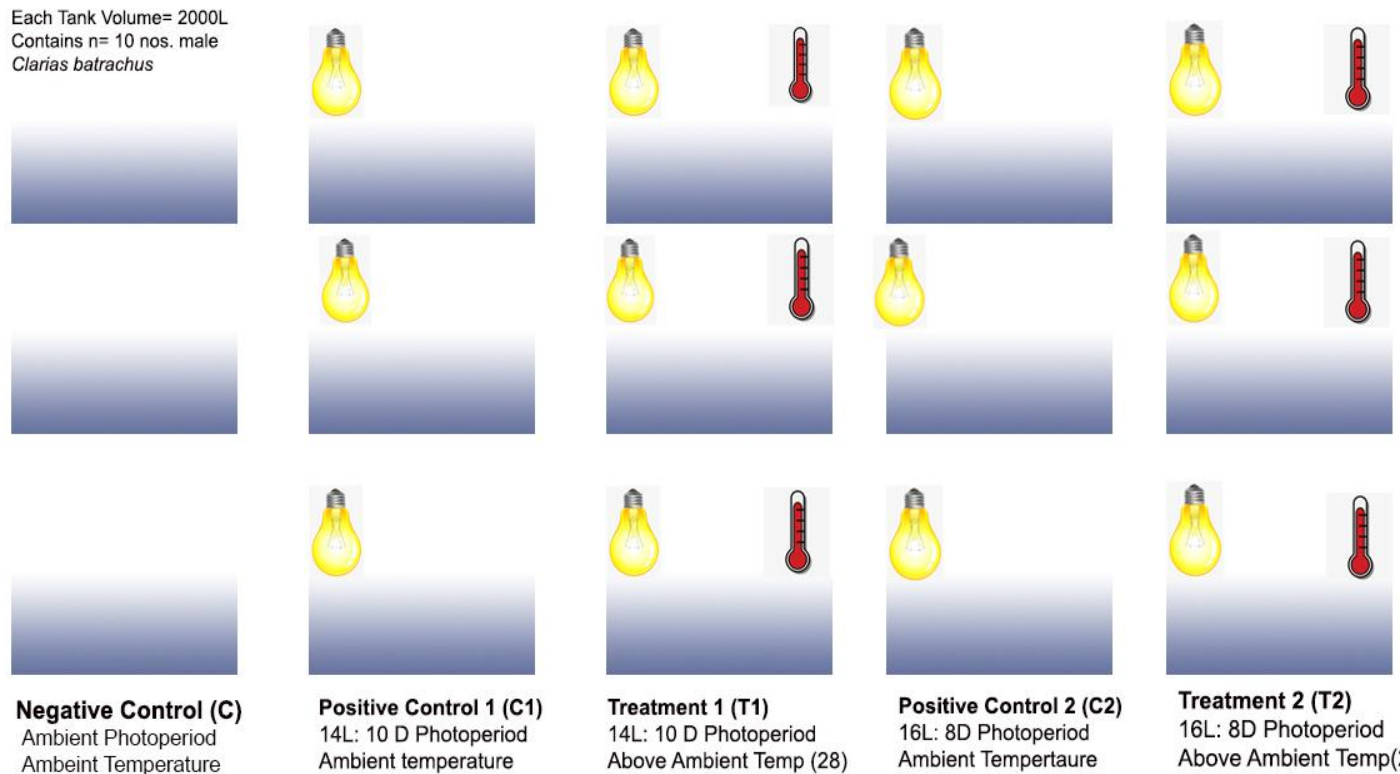

Treatment 1 (T1)

14L: 10 D Photoperiod

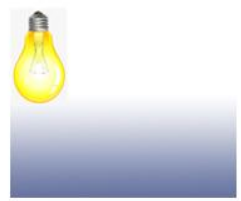

Positive Control 2 (C2) 16L: 8D Photoperiod Ambient Tempertaure

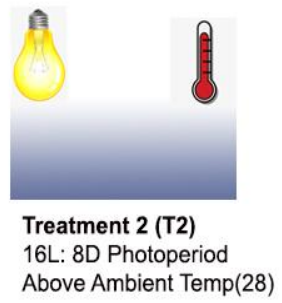

\section{Experimental Design}

Fig.2 Trend of gonadosomatic index (GSI) as expressed as mean \pm SEM for various treatment and control groups ( $\mathrm{C} 0, \mathrm{C} 1$ and $\mathrm{C} 2)$ over the treatments (T1 and $\mathrm{T} 2)$ for three sampling periods.

Asterix (*) denotes significant difference noted between the GSI of T1 and T2 (p < 0.05).

\section{Gonadosomatic Index (GSI)}

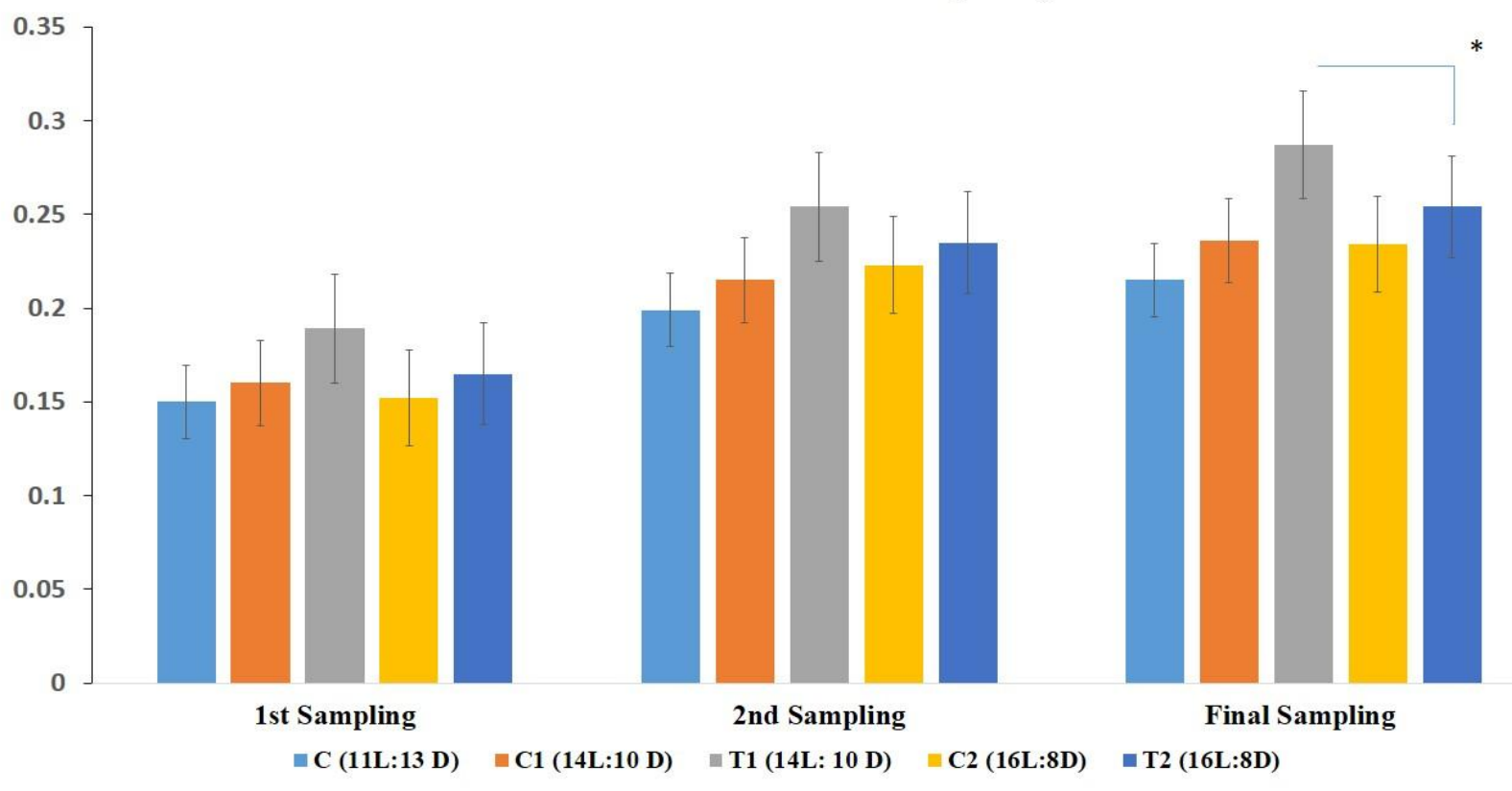


Fig.3 Trend of Seminal vesicle Somatic index (SVSI) as expressed in terms of mean \pm SEM for various treatment and control groups $(\mathrm{C} 0, \mathrm{C} 1$ and $\mathrm{C} 2)$ over the treatments $(\mathrm{T} 1$ and $\mathrm{T} 2)$ for three sampling periods. Asterix (*) denotes significant difference noted between the GSI of T1 and T2 $(\mathrm{F}=4.985 ; \mathrm{p}<0.05)$.

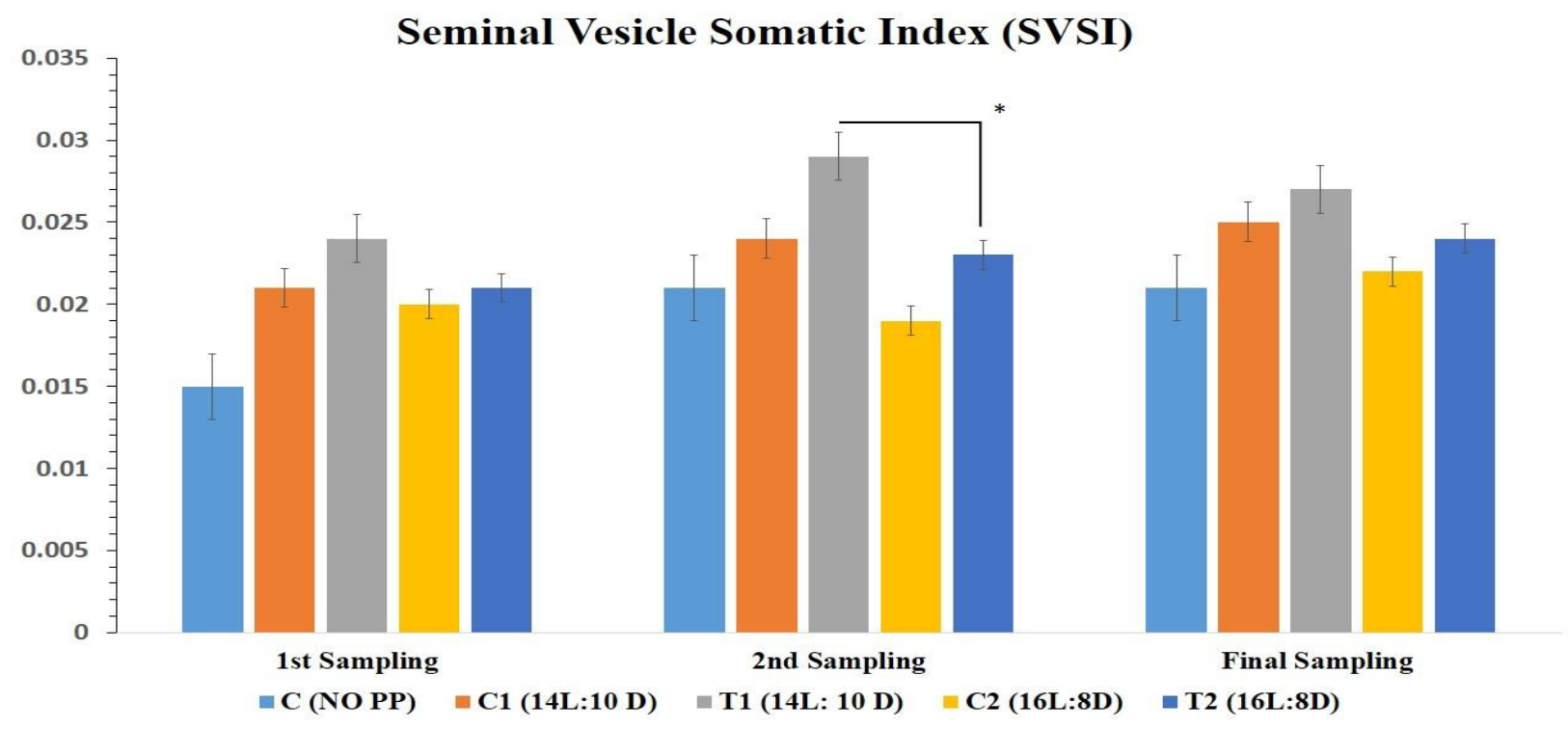

Fig.4 Histological sections showing the effect of temperature in combination with Long Photoperoid 1 (14L:10 D) and Long photoperiod 2 (16L: 8D) on the male gonads of Clarias magur in treatment 1 (A) and treatment 2 (B). The respective parallel controls $(\mathrm{C} 1$ and $\mathrm{C} 2)$ are shown in plates $\mathrm{B}$ and $\mathrm{D}$ respectively. Plate A denotes the negative control $(\mathrm{C} 0)$. Various cell

types are marked with arrows with abbreviations $(\mathrm{SC}=$ Spermatocytes, $\mathrm{SSC}=$ Secondary Spermatocytes, SZ= Spermatozoa).

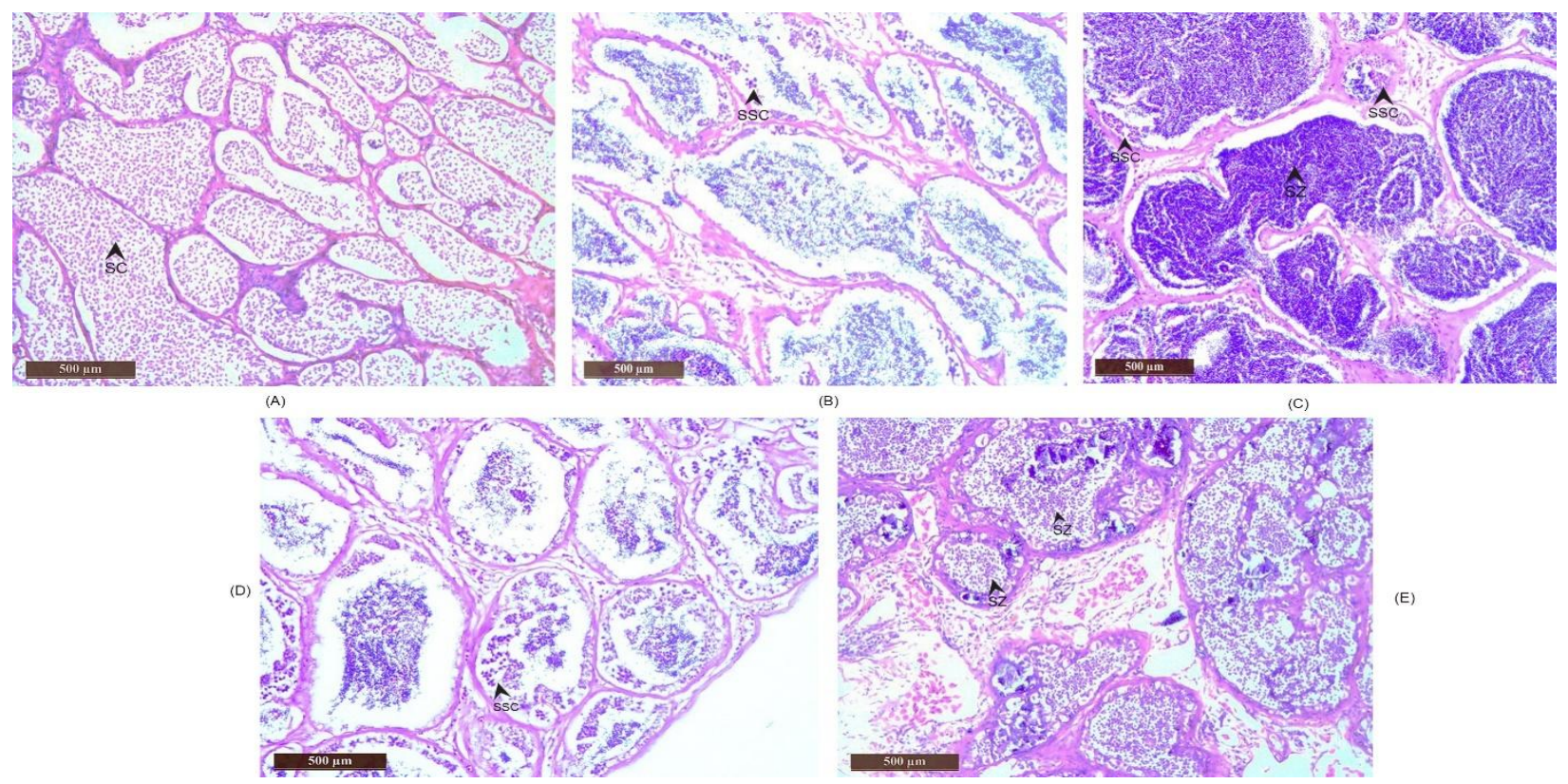


Fig.5 Percentage distribution of cells in testis of control (C0, $\mathrm{C} 1$ and $\mathrm{C} 2)$ and treatments (T1 and T2).

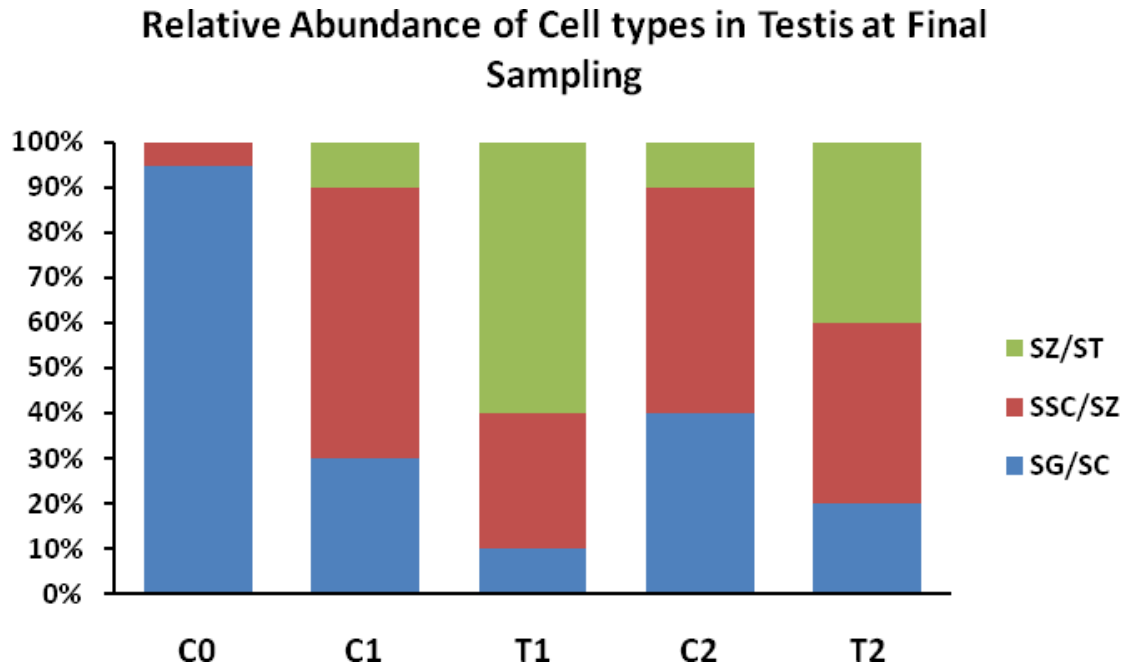

The other treatment (T2; Long Photoperiod 16L: $8 \mathrm{D}$ at $28{ }^{\circ} \mathrm{C}$ ) also showed better maturity in comparison to the parallel control or negative control however the lobules are not filled with SZ as seen in T1 and the maturity stage can be correlated to being that of a matured fish in wild.

The relative abundance of the cell types is given in Fig 5. It can be seen that the similar results were manifested in the relative abundance of the cell types where the negative control has very less percentage of differentiated cell types (SSC/SZ) and comprises mostly of the undifferentiated Speramtogonia/Spermatocytes (SG/SC). In the positive controls ( $\mathrm{C} 1$ and $\mathrm{C} 2)$ there is increase in the number of Secondary Speramtocytes and few spermatozoa can also be seen.

Photoperiod is often regarded as the most noise free environmental cue which is perceived by the fishes to control their biological rhythms. The work with photothermal manipulation in fishes is not new for aquaculturists. However, it is yet to be a viable technology in terms of user friendliness as farmers find it difficult to simulate the experimental conditions at farms level. In early eighties, such studies have been performed for Heteropnesuestes fossilis (Garg et al., 1985) and authors reported the efficacy of the use of 14L: $10 \mathrm{D}$ photophase regime in expediting the gonadal maturity in the male fishes. We obtained the similar results in this study by using a combination of long Photoperoid (14L: 10D) and above ambient temperature $\left(28^{\circ} \mathrm{C}\right)$. In the present study a comparison was made between two long (14L:10 D and 16L:8D) photophasic regime in presence and absence of temperature.

Acharia et al., $(2000,2014)$ concluded that in female Clarias batrachus temperature-induced gonadal recrudescence would occur only following coincidence of high temperature with the thermo-inducible phase. The underlying mechanism of this phenomenon might be circadian in nature. Further studies with Neuropeptide Y (NPY) in Ovarian follicles of $C$. batrachus it was suggested that photoperiod and temperature both affect NPY expression and ovarian recrudescence in fish but the influences of temperature seem to be 
more prominent (Singh and Lal, 2019). This study shows that the photoperiod 14L: 10D is most suited for eliciting early maturity in male Clarias magur in the early preparatory phases. Being nocturnal, the fishes undergo severe stress if exposed to a continuous photophasic regime (24L: 0D) as measured by the spikes in their haematological parameters (Srivastava and Chowdhury, 2010). Even with the Photoperiodic regime of 16L: 8D, the fishes show delayed maturity over the photoperiod in control (11L: 13D). Chaube et al., (2020) reported that the exposure of the $H$. fossilis to long photoperiod (LP, $16 \mathrm{~h}$ light) at high temperature (HT, $28{ }^{\circ} \mathrm{C}$ ) stimulated both kiss 2 and gnrh2 expression maximally however in our case the fishes showed a better response to the comparatively er photoperiod coupled with temperature (14L: 10D). This may be attributed due to the fact that for their experiment the short photoperiod was selected as 8L:16 D but in our case only long photoperiods were considered (14L: $10 \mathrm{D}$ and 16L:8D) corroborating to similar results.

Furthermore, this study aims at providing a simple low cost setup for the catfish farmers who can use FRP or cemented tanks to hold Clarias magur male brooders and use LED bulbs for illumination, heaters for creating above ambient temperature or thermopulse and tarpaulin to cover the top to prevent the ambient light from entering the setup. This study provides the scope for ensuring synchronicity of the brooders of male and female Clarias magur to provide better reproductive output. In a recent finding it is also reported that there is temperature dependent increment of Growth hormone in Clarias batrachus subjected to photothermal manipulation (Gopal et al., 2014). So, there is scope of further studies that whether such photothermal intervention can result in better growth and survivability of the offsprings. Photothermal manipulation is one of the oldest and best suited mechanisms for the environmental manipulation of the biological rhythms in teleosts. As in the case of many non-air breathing fishes, Photothermal manipulation effectively results in advancement of the gonadal maturity of the fishes. Rarely we encounter male sex specific studies in air breathing fishes and this study has shown promising results if this technology being effectively used as a tool to expedite the male gonadal maturity in male Clarias magur using combination of photoperiod (14L: $10 \mathrm{D})$ and temperature $\left(28{ }^{\circ} \mathrm{C}\right)$. Catfish farmers can effectively adopt such low-cost setup to attain mature male Clarias magur in the month of April or May so that they can start their breeding cycle one month in advance.

\section{Acknowledgement}

The authors are indebted to the Director, ICAR-Central Institute of Fisheries Education, Mumbai and OIC, ICAR-Central Institute of Fisheries Education, Kolkata Centre for providing necessary infrastructure for carrying out the research.

\section{Conflict of Interest}

The authors declare that they have no conflict of interest.

\section{References}

Acharia, K., Lal, B., and Singh, T. P. 2014. Season-dependent effect of thermopulse on gonadal recrudescence in the female catfish, Clarias batrachus. Indian Journal of Experimental Biology, 52: 538-541.

Al-Khamees, S. A. 2009. Photoperiod effects on circadian rhythms and puberty onset in African catfish Clarias gariepinus. Ph.D Thesis, University of Sterling, Netherlands.

APHA, AWWA and WEF. (1995). Standard Methods for the Examination of Water, 
Waste Water and Sewage. 19th ed.APHA. Inc., Washington DC.

Bhattacharyya, S., Dey, R., and Maitra, S. K. 2005. Photoperiodic regulation of annual testicular events in the Indian major carp Catla catla. Acta Zoologica, 86(2): 71-79.

Bisht, A., Anand, S., Bhadula, S., and Pal, D. 2013. Fish seed production and hatchery management: A Review. New York Science Journal, 6:42-48.

Chaube, R., Sharma, S., Senthilkumaran, B., Bhat, S. G., and Joy, K. P. 2020. Expression profile of kisspeptin2 and gonadotropin-releasing hormone2 mRNA during photo-thermal and melatonin treatments in the female airbreathing catfish Heteropneustes fossilis. Fish Physiology and Biochemistry, 46(6), 2403-2419.

Chowdhury, I., and Joy, K. P. 2001. Seminal vesicle and testis secretions in Heteropneustes fossilis (Bloch): composition and effects on sperm motility and fertilization. Aquaculture, 193(3-4), 355-371.

Garg, S. K. 1987. Seasonal effects of pinealectomy of testicular recrudescence and secretory activity of seminal vesicle in the catfish, Heteropneustes fossilis (Bloch). Journal of Fish Biology 3: 1-7.

Garg, S. K. and Jain, S. K. 1985. Effect of photoperiod and temperature on ovarian activity in the Indian murrel, Channa (Ophicephalus) punctatus (Bloch). - Canadian Journal of Zoology 63: 834-842.

Garg, S. K. and Sundararaj, B. I. 1985. Response of the testes and seminal vesicle of the catfish, Heteropneustes fossilis (Bloch) to various combinations of photoperiod and temperature. - Physiological Zoology 58: 616-627.

Gupta, B. B. P., and Premabati, Y. 2002.
Differential effects of melatonin on plasma levels of thyroxine and triiodothyronine levels in the airbreathing fish, Clarias gariepinus, during breeding and quiescent periods. General and comparative endocrinology. 129(3): 146-151.

IUCN, 2020. The IUCN Red List of Threatened Species. Version 2020-2.. Downloaded 16 July 2020.

Acharia, K., Lal, B., Singh, T. P. and Pati, A. K. 2000. Circadian Phase Dependent Thermal Stimulation of Ovarian Recrudescence in Indian Catfish, Clarias batrachus, Biological Rhythm Research, 31(2): 125-135.

Priyadarshini \& Lal, B. (2018). Seasonal ovarian immunolocalization of neuropeptide $\mathrm{Y}$ and its role in steriodogenesis in Asian catfish, Clarias batrachus. General and comparative endocrinology, 255, 3239.

Sarkar, S. K., A. Saha, S. Dasgupta, S. Nandi, D.K. Verma, P. Routray,... and Ayyappan, S. 2010. Photothermal manipulation of reproduction in Indian major carp: a step forward for offseason breeding and seed production. Current science. 99(7): 960-964.

Senthilkumaran, B., and Joy, K. P. 1995. Changes in hypothalamic catecholamines, dopamine- $\beta$ hydroxylase, and phenylethanolamine$\mathrm{N}$-methyltransferase in the catfish Heteropneustes fossilis in relation to season, raised photoperiod and temperature, ovariectomy, and estradiol-17 $\beta$ replacement. General and Comparative Endocrinology, 97(1): 121-134.

Singh, K. M., S. Saha, and Gupta, B. B. P. 2017. Season-dependent effects of photoperiod and temperature on circadian rhythm of arylalkylamine $\mathrm{N}$ acetyltransferase 2 gene expression in 
pineal organ of an air-breathing catfish, Clarias gariepinus. Journal of Photochemistry and Photobiology B: Biology, 173, 140-149.

Singh, P., and Lal, B. 2019. Photo-thermal regulation of neuropeptide Y (NPY) expression in ovarian follicles and ovarian activity of the catfish, Clarias batrachus. General and comparative endocrinology, 279: 114-119.

Srivastava, S., and Choudhary, S.K. 2010.Effect of artificial photoperiod on the blood cell indices of the catfish,Clarias batrachus. Journal of Stress Physiology \& Biochemistry, 6(1): $22-32$.

Sundararaj, B. I. and Vasal, S. 1973. Photoperiod regulation of reproductive cycle in the catfish, Heteropneustes fossilis (Bloch). IV International congress of Endocrinology, Washington DC, - Excerpta Medical International Congress series 1972: 273.

Sundararaj, B. I. and Vasal, S. 1976. Photoperiod and temperature control in the regulation of reproduction in the female catfish Heteropneustes fossilis. - Journal of Fish Research Biologyl Canada 33: 959-973.

Sundararaj, B. I., and Sehgal, A. 1970. Effects of a long or an increasing photoperiod on the initiation of ovarian recrudescence during the preparatory period in the catfish, Heteropneustes fossilis (Bloch). Biology of reproduction, 2(3): 413-424.

Swapna, I., M. Rajasekhar, A. Supriya, K. Raghuveer, G. Sreenivasulu, M. K. Rasheeda,... and Senthilkumaran, B. 2006. Thiourea-induced thyroid hormone depletion impairs testicular recrudescence in the air-breathing catfish, Clarias gariepinus. Comparative Biochemistry and Physiology Part A: Molecular \& Integrative Physiology, 144(1): 1-10.

Vasal, S. and Sundararaj, B. I. 1976. Response of the ovary in the catfish, Heteropneustes fossilis (Bloch), to various combinations of photoperiod and temperature. - Journal of Experimental Zoology 197: 247-264

\section{How to cite this article:}

Srijit Chakravarty, N. K. Chadha, B. K. Mahapatra, Paramita Bannerjee Sawant and Subrata Dasgupta. 2021. Temperature Accelerates Photoperiod Mediated Testicular Maturity in Clarias magur (Hamilton, 1822). Int.J.Curr.Microbiol.App.Sci. 10(08): 500-509. doi: https://doi.org/10.20546/ijcmas.2021.1008.060 